\title{
Survival of Saplings in Recovery of Riparian Vegetation of Pandeiros River (MG)
}

\author{
Nathalle Cristine Alencar Fagundes ${ }^{1}$, Lílian de Lima Braga ${ }^{2}$, Wesley Alves Silva ${ }^{3}$, \\ Chirley Alves Coutinho ${ }^{3}$, Walter Viana Neves ${ }^{4}$, Ricardo Almeida de Souza ${ }^{5}$, \\ Maria das Dores Magalhães Veloso ${ }^{3}$, Yule Roberta Ferreira Nunes ${ }^{3}$
}

${ }^{1}$ Programa de Pós-graduação em Botânica Aplicada, Universidade Federal de Lavras - UFLA, Lavras/MG, Brazil ${ }^{2}$ Programa de Pós-graduação em Ciências Biológicas, Universidade Estadual de Montes Claros - UNIMONTES, Montes Claros/MG, Brazil

${ }^{3}$ Departamento de Biologia Geral, Universidade Estadual de Montes Claros - UNIMONTES, Montes Claros/MG, Brazil ${ }^{4}$ Diretoria de Fiscalização Ambiental/Norte Minas, Sistema Estadual de Meio Ambiente, Montes Claros/MG, Brazil ${ }^{5}$ Instituto Federal do Norte de Minas Gerais - IFNMG, Januária/MG, Brazil

\begin{abstract}
This study monitored the survival of saplings planted according to different recovery models in a riparian forest of the Pandeiros river (Januária, MG). The models consisted of planting the saplings in lines of 2 or $4 \mathrm{~m}$ with presence (T2S and T4S, respectively) or absence of direct seeding (T2 and T4, respectively). We planted 16,259 saplings of 17 botanical families, 32 genera and 33 species. The saplings, in general, presented a survival rate after one year of $34.4 \%( \pm 1.8)$. The species with highest survival rates were Jacaranda brasiliana, with $85.0 \%( \pm 13.5)$ of survival, Anadenanthera colubrina, with $70.1 \%( \pm 7.0)$, and Triplaris gardneriana, with $69.3 \%( \pm 9.1)$. Survival did not vary between the models tested, probably due to the short evaluation period (12 months).
\end{abstract}

Keywords: recovery models, planting of saplings, direct seeding. 


\section{INTRODUCTION}

The Cerrado, a region of considerable biological diversity, is identified as one of the richest and most threatened ecosystems in the world, with a large number of restricted and specialized endemic species (about $44 \%$ of the flora), which are therefore susceptible to extinction (Scariot et al., 2005). This biome is considered a conservation priority for global biodiversity, since $55 \%$ of its original area was deforested or transformed by human action (Klink \& Machado, 2005). The relatively flat surface and the presence of fertile soils promotes the highest and fastest rates of agricultural growth in Brazil, being considered the last agricultural frontier of the country, attracting a significant part of the national agribusiness (Klink \& Machado, 2005).

In this context, the riverine formations (ciliar, riparian or gallery forests) that occur in the Cerrado show the effects of this agricultural expansion and represent environments significantly disturbed and degraded by anthropic action. Riparian forests protect and maintain water resources, since they are formations associated with watercourses, standing out for their richness and genetic diversity and acting as a physical barrier between terrestrial and aquatic systems (Hughes et al., 2008; Roni \& Beechie, 2013). These forests act to filter water flowing into the watercourses along which they are found, developing conditions conducive to infiltration and significantly reducing the possibility of water contamination by sediment, fertilizer residues and agricultural pesticides (Ribeiro \& Schiavini, 1998; Roni \& Beechie, 2013). Additionally, they are important ecological corridors for the movement of fauna and gene flows (Martins, 2007). Thus, given these particular characteristics that highlight their importance, forests bordering streams and springs, are protected by federal legislation and are considered Permanent Preservation Areas (PPAs), according to the Forest Code, Law (number 12.651 of May $25^{\text {th }}$ 2012), that is, an ecological reserve that cannot undergo alteration, and whose vegetation must remain intact in its original state (Brasil, 2012).

Even when protected by law, PPAs are not exempt from the impacts of human activity, both in the surroundings and in loco (Rezende, 2004). In this sense, the recovery of degraded areas has become a priority to combat the environmental degradation processes to which natural areas are exposed (Martins, 2007). However, to recover degraded areas, it is necessary to establish a model developed from studies of phenology, details regarding the biology and germination of species, and growth analysis, amongst others, that are fundamental for vegetation rehabilitation (Hughes et al., 2008; Andel et al., 2012). Thus, techniques in combination such as sapling planting and direct seeding, which aim to guard against soil erosion and assist local revegetation, can offer good outcomes, which help to ensure the successful recovery of degraded areas (Martins, 2007; Roni \& Beechie, 2013).

In order to restore vegetation and ecological processes, several models for the recovery of degraded areas have been tested (Andel et al., 2012; Pereira \& Rodrigues, 2012). Most studies are based on successional models (McClain et al., 2011) with species of different ecological groups (Gonçalves et al., 2005; Pereira \& Rodrigues, 2012) or by facilitating species (Beltrame \& Rodrigues, 2008). However, according to Tilman (1988), in nutrient-deficient environments (such as disturbed and degraded environments), competition between species may be a determining factor for their establishment. Despite the importance of competition for seedling/sapling survival and growth, studies with recovery models of degraded areas based on distances between saplings to test the effect of competition, are scarce.

The Environmental Protection Area (EPA) of Pandeiros River was established by Law 11,901 of September $1^{\text {st }} 1995$, with the objective of conserving the water resources and significant biological diversity present at the site (Nunes et al., 2009). The Pandeiros River EPA is located in northern Minas Gerais, an ecotonal area between the Cerrado and Caatinga domains, forms a junction between riparian forest, dry forest, cerrado (savanna) and veredas (palm swamps), occurring in alternating areas that may show abrupt vegetation changes within relatively small areas (Nunes et al., 2009). Among these physiognomies, the riparian forests, characterized by accompanying springs and water courses (Andel et al., 2012; Roni \& Beechie, 2013) form ecological corridors that highlight the botanical diversity present, as well as protecting and sheltering terrestrial and aquatic fauna (Roni \& Beechie, 2013). 
Despite the protection afforded by Law (both PPAs and EPAs), there are several factors, mainly livestock and fires that impact the riparian forest of Pandeiros river compromising local biodiversity conservation and making the forest sparse and even wholly absent (Nunes et al., 2009; Rodrigues et al., 2009). In this sense, this study aimed to monitor the survival of saplings of native species planted according to different recovery models for the riparian vegetation of the Pandeiros River, to evaluate the most effective rehabilitation model for riparian forests in the region.

\section{MATERIAL AND METHODS}

\subsection{Characterization of study area}

This work was developed at the Pandeiros River EPA, Januária, northern Minas Gerais, Brazil. The region presents several phytophysiognomies, resulting from the transition between the Cerrado and Caatinga biomes, such as the Deciduous Seasonal Forest (dry forest), cerrado sensu stricto, riparian forests, floodplain areas and veredas (Nunes et al., 2009). Additionally, the riparian vegetation of the Pandeiros River presents a junction of riparian forest, dry forest, savanna, and palm swamps, exhibiting high tree diversity (Rodrigues et al., 2009; Menino et al., 2012; Veloso et al., 2014).

The climate of the region, according to Köppen, is $\mathrm{Aw}$, with average annual temperature of 21 to $24^{\circ} \mathrm{C}$ and rainfall of 900 to $1,200 \mathrm{~mm}$, and rainfall concentrated in the months of November to January (Azevedo et al., 2014). During the study period, the average temperature was $24.3{ }^{\circ} \mathrm{C}$ and $23.6{ }^{\circ} \mathrm{C}$, the maximum average temperature was $31.9^{\circ} \mathrm{C}$ and $31.3^{\circ} \mathrm{C}$, minimum average temperature was $18.4{ }^{\circ} \mathrm{C}$ and $17.5^{\circ} \mathrm{C}$ and total precipitation was $1,302.6 \mathrm{~mm}$ and $1,877.4 \mathrm{~mm}$, throughout the period from December 2009 to December 2010 and from January 2011 to December 2011, respectively. The rains were concentrated during the summer, with peaks in December/2009, March and December/2010 and March and December/2011 (Figure 1). The highest temperatures were observed in January and October/2010 and February and September/2011. The climatic data were obtained from the Meteorological Station of Januária, of the National Meteorological Institute (INMET 2016).

Geomorphologically, the EPA of Pandeiros River is located in the São Fransiscana Depression and São Francisco Planalto, with a geological process of the Urucuia and Santa Helena Formations (sedimentary material) and limestone layers of the Bambuí Series (Jacomine, 1979). The predominant soil is the typical Dystrophic Red-Yellow Latosol, with a moderate A horizon and clayey texture, cerrado phase, with smooth to wavy relief, where there are spots of typical Eutrophic Haplic Cambisol with moderate A horizon and clayey texture added to the Argisol Red-Typical eutrophic yellow, with moderate A and clayey texture, deciduous forest phase, with flat to soft undulating relief (UFV, 2010a, b).

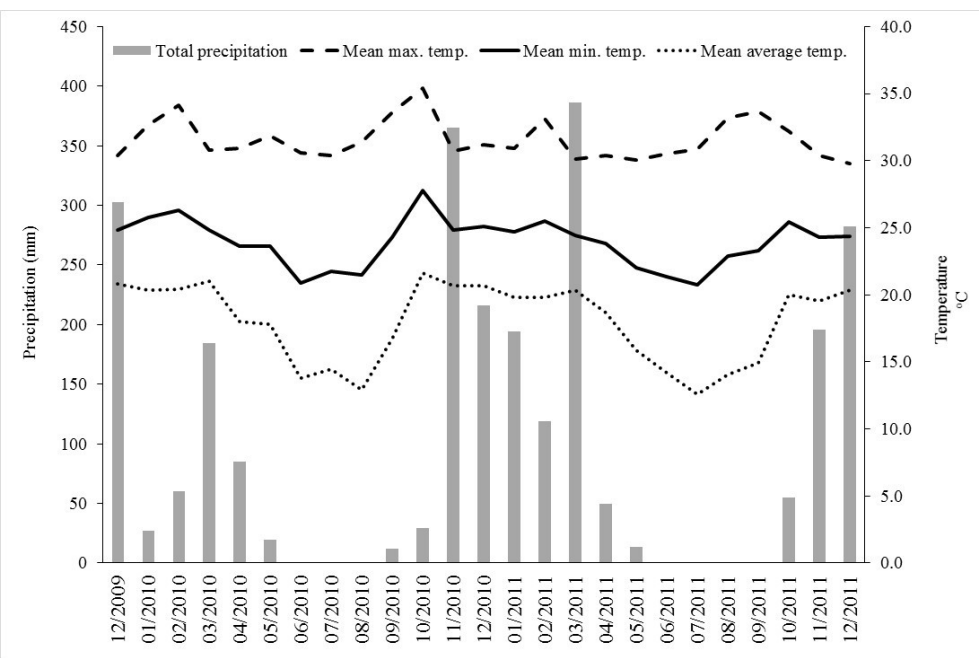

Figure 1. Mean monthly of minimum, average and maximum temperature and total monthly precipitation from December 2009 to January 2011, obtained at the Meteorological Station of Januária, Minas Gerais (Source: INMET, 2016). 
For the experiment implementation, the areas destined for the revegetation were the PPAs, demarcated by the Brazilian Forest Code (Brasil, 1965), in the year of implantation of the experiment (2009). The experiment was conducted on three farms: Agropecuária Ouro Preto - AGROPOP ( $15^{\circ} 36^{\text {“S }}$ and $44^{\circ} 42^{\prime}$ " W), Traçadal

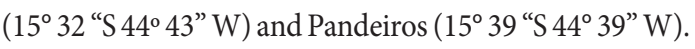
All farms present extensive cattle breeding as an economic activity, where the areas used were deforested for cultivation of Brachiaria sp. Experimental plantations were carried out in December 2009, at AGROPOP, January 2010, at Traçadal, and December 2010 at Pandeiros farms.

\subsection{Species selection, sapling production and recovery models}

The native species used for recovery planting were species that occur in the region and were selected from floristic studies conducted in the riparian vegetation of the Pandeiros river, near the study areas (Rodrigues et al., 2009; Veloso et al., 2014). About 10 matrices for each species were marked for seed collection, close to the study areas, but from different forest remnants, to guarantee genetic diversity (Martins, 2007). Seed collection and sapling production were undertaken in partnership with the Instituto Estadual de Florestas (IEF), using the IEF forest nursery in Januária, as well as the Plant Ecology Laboratory of the Universidade Estadual de Montes Claros (UNIMONTES).

Four different recovery models were implemented, with four replications each, consisting of 1.0 ha plots (50 $\mathrm{m}$ wide perpendicular to the river $\times 200 \mathrm{~m}$ long parallel to the river). Each plot was demarcated using treated eucalyptus fence and barbed wire. Treatment of the area was also undertaken, consisting of harrowing, with a tractor, and applying organic matter (chicken manure or mamona cake, used $0.5 \mathrm{t}$ per area) manually. Harrowing was realized to decrease Brachiaria sp. grasses from the planting site, to incorporate the organic matter and for soil turning.

To plant the saplings, a fixed spacing of $2 \mathrm{~m}$ between the planting lines was applied and saplings were planted in $20 \mathrm{~cm}$ deep pits. The treatments $(\mathrm{T})$, or implanted recovery models, consisted of planting saplings at two distances of either 2 or $4 \mathrm{~m}$, with direct sowing - S (T2S and T4S, respectively) or no direct sowing (T2 and T4, respectively). The direct sowing in the soil was done between the saplings, with three seeds per hole, using holes of approximately $5 \mathrm{~cm}$ made with a hoe. The species used in direct seeding and the amount of seeds used (by weight) are described in Table 1. The experiment was carried out during the rainy season, aiming to reduce transplanting stress, since during this period the water supply would be sufficient for the establishment and growth of saplings and seed germination.

A total of 16,259 saplings were planted, distributed in 33 species, 32 genera and 16 families (Table 1), ranging from $20 \mathrm{~cm}$ to $1 \mathrm{~m}$ in height, all of them over four months old. After planting, the saplings were numbered with aluminum plates and tied by a nylon thread, and the survival of these saplings was monitored every four months for a year.

\subsection{Data analysis}

The survival rate of the individuals was determined by the ratio between the number of surviving individuals and the total number of individuals planted for each species and treatment throughout the four evaluations. To detect variations in survival of individuals between recovery models and between planted species, Variance Analysis (ANOVA) was used in GLM (Generalized Linear Models) procedure, followed by Tukey's post-test in the R (R Development Core Team, 2013) statistical package.

\section{RESULTS}

The total survival percentage showed significant variation between the evaluation months $(\mathrm{df}=3, \mathrm{~F}=75.98, \mathrm{p}<0.001)$. The highest survival rate of the planted saplings was $70.3 \%( \pm 1.8)$, after three months of evaluation, with values of $64.0 \%$ $( \pm 1.8)$ after six months, and $51.0 \%( \pm 1.9)$ nine months after planting. After 12 months of evaluation, survival dropped to $34.4 \%$ ( \pm 1.8 ), showing that survival decreased significantly during the first year of experimental planting (Figure 2). However, there was no significant variation $(\mathrm{df}=3, \mathrm{~F}=2.58, \mathrm{p}>0.05)$ in survival rates between the models tested. The mean survival percentage was numerically higher in the model with sapling and direct sowing at $2 \mathrm{~m}$ distance 
Table 1. Native species used in direct seeding (weight in grams) and sapling planting (number of individuals) in the recovery of riparian vegetation of Pandeiros river (Januária, MG).

\begin{tabular}{|c|c|c|c|}
\hline Family/ species & Common name & Direct seeding (g) & Sapling planting \\
\hline \multicolumn{4}{|l|}{ Anacardiaceae } \\
\hline Anacardium humile A. St.-Hil. & Cajuí & 1384.16 & 62 \\
\hline Anacardium occidentale L. & Cajueiro & 253.08 & 96 \\
\hline Astronium fraxinifolium Schott ex Spreng. & Gonçalo & 1045.92 & 1400 \\
\hline Myracrodruon urundeuva Allemão & Aroeira & 1587.31 & 1364 \\
\hline Schinopsis brasiliensis Engl. & Pau-preto & 261.76 & 508 \\
\hline Tapirira guianensis Aubl. & Tapiriri & 2665.28 & - \\
\hline \multicolumn{4}{|l|}{ Annonaceae } \\
\hline Annona crassiflora Mart. & Cabeça-de-negro & - & 516 \\
\hline \multicolumn{4}{|l|}{ Apocynaceae } \\
\hline Aspidosperma subincanum Mart. ex A. DC. & Pau-pereiro & 1007 & 294 \\
\hline \multicolumn{4}{|l|}{ Bignoniaceae } \\
\hline Handroanthus chrysotrichus (Mart. ex A. DC.) Mattos & Ipê-tabaco & 240 & 345 \\
\hline Jacaranda brasiliana (Lam.) Pers. & Caroba & - & 187 \\
\hline Tabebuia sp. & Ipê & 1362.64 & 1426 \\
\hline \multicolumn{4}{|l|}{ Burseraceae } \\
\hline Commiphora leptophloeus (Mart.) J.B.Gillet & Umburana-vermelha & - & 137 \\
\hline \multicolumn{4}{|l|}{ Cannabaceae } \\
\hline Celtis iguanaea (Jacq.) Sarg. & Juá-mirim & - & 21 \\
\hline \multicolumn{4}{|l|}{ Combretaceae } \\
\hline Combretum duarteanum Cambess. & Vaqueta & 2073.92 & \\
\hline \multicolumn{4}{|l|}{ Dilleniaceae } \\
\hline Curatella americana $\mathrm{L}$. & Lixeira & 200.64 & 21 \\
\hline \multicolumn{4}{|l|}{ Fabaceae-Caesalpinioideae } \\
\hline Caesalpinia ferrea Mart. Ex Tul. & Pau-ferro & 16307 & 53 \\
\hline Copaifera coriacea Mart. & Pau-d’olinho & & 612 \\
\hline Dimorphandra mollis Benth. & Favela & 1424.64 & \\
\hline Hymenaea eriogyne Benth. & Jatobá & 5919.4 & \\
\hline Hymenaea martiana Hayne & Jatobá & 3875.04 & \\
\hline Hymenaea sp. & Jatobá & - & 965 \\
\hline Senna spectabilis (DC.) H.S.Irwin \& Barneby & São-joão & - & 516 \\
\hline \multicolumn{4}{|l|}{ Fabaceae-Faboideae } \\
\hline Bowdichia virgilioides Kunth & Sucupira-preta & 52.8 & - \\
\hline Machaerium opacum Vogel & Jacarandá-do-cerrado & 4408.72 & - \\
\hline Plathymenia reticulata Benth. & Vinhático & 417 & - \\
\hline Pterodon emarginatus Vogel & Sucupira-branca & 3957.76 & - \\
\hline Swartzia flaemingii Vogel & Pau-sangue & 423.28 & - \\
\hline Vatairea macrocarpa Ducke & Angelim & 430.36 & 9 \\
\hline \multicolumn{4}{|l|}{ Fabaceae-Mimosoideae } \\
\hline Anadenanthera colubrina (Vell.) Brenan & Angico & 869 & 1883 \\
\hline Chloroleucon dumosum (Benth.) G.P.Lewis & Rosqueira & 896 & 144 \\
\hline $\begin{array}{l}\text { Chloroleucon foliolosum (Benth.) } \\
\text { G. P. Lewis }\end{array}$ & Tatarena & 1768 & - \\
\hline Enterolobium contortisiliquum (Vell.) Morong & Tamboril & 5438 & 218 \\
\hline Inga vera Willd. & Ingá & - & 80 \\
\hline Machaerium punctatum (Poir.) Pers. & Jacarandá & 930 & - \\
\hline Senegalia polyphylla (DC.) Britton \& Rose & Periquiteira & 1021 & 143 \\
\hline \multicolumn{4}{|l|}{ Malvaceae } \\
\hline Guazuma ulmifolia Lam. & Mutamba & - & 524 \\
\hline \multicolumn{4}{|l|}{ Myrtaceae } \\
\hline Eugenia dysenterica DC. & Cagaita & - & 585 \\
\hline \multicolumn{4}{|l|}{ Memecylaceae } \\
\hline Mouriri pusa Gardner & Pusa-preta & 1534.08 & - \\
\hline Polygonaceae & & & \\
\hline Triplaris gardneriana Weddell & Pau-jaú & 390 & 967 \\
\hline Rhamnaceae & & & \\
\hline Ziziphus joazeiro Mart. & Juazeiro & - & 345 \\
\hline Rubiaceae & & & \\
\hline Genipa americana $\mathrm{L}$. & Jenipapo & - & 600 \\
\hline Sapindaceae & & & \\
\hline Dilodendron bipinnatum Radlk. & Mamoninha & 1090.12 & 376 \\
\hline Magonia pubescens A.St.-Hil. & Tingui & 9454.6 & 506 \\
\hline Talisia esculenta (A.St.-Hil.) Radlk. & Pitomba & - & 273 \\
\hline Sterculiaceae & & & \\
\hline Sterculia striata A.St.-Hill. \& Naudin & Chichá & 1271 & 41 \\
\hline Urticaceae & & & \\
\hline Cecropia pachystachya Trécul & Embaúba & - & 1042 \\
\hline
\end{tabular}


between saplings - ST2 $(57.3 \pm 1.9 \%)$ and lower in the model with saplings at $4 \mathrm{~m}$ distance and absence of sowing - T4 (50.2 $\pm 2.0 \%)$. On the other hand, there was a decrease in survival in all treatments tested, over time, as observed between areas and between months of treatment.

The survival rate also showed significant variation between the study areas $(\mathrm{df}=2, \mathrm{~F}=109.83, \mathrm{p}<0.001)$. The area that presented the highest survival rate was AGROPOP $(76.6 \pm 1.7 \%)$, followed by Traçadal $(47.2 \pm 2.1 \%)$ and Pandeiros (46.2 $\pm 1.3 \%)$, which showed the lowest survival rates (Figure 3). Survival varied between the study months in the areas studied, but decreased over time in the three areas.

The species with the highest average survival rate after one year of evaluation were Jacaranda brasiliana (caroba), with 85.0\%, Anadenanthera colubrina (angico), with $70.1 \%$, Triplaris gardneriana (pau-jaú), with 69.3\%, Senna spectabilis (são-joão), with 68.8\%, and Caesalpinia ferrea (pau-ferro), with 63.8\% (Table 2). On the other hand, some species had a low average survival rate, such as Ziziphus joazeiro (juazeiro), with $1.50 \%$ and Anacardium humile (cajui), with $8.03 \%$, while all Inga vera (ingá) saplings died.

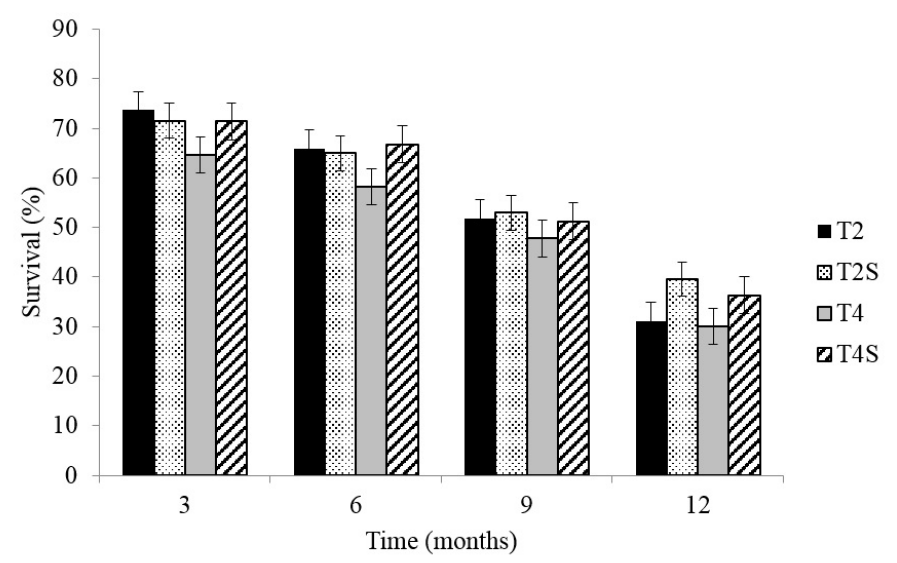

Figure 2. Average survival percentage of saplings implanted in the restoration of riparian vegetation of Pandeiros river (Januária, MG), for restoration model and evaluation time. Restoration models: sapling planting with distance between rows of $2 \mathrm{~m}$ without (T2) and with (T2S) direct seeding and in lines of $4 \mathrm{~m}$ without (T2) and with (T2S) direct seeding.

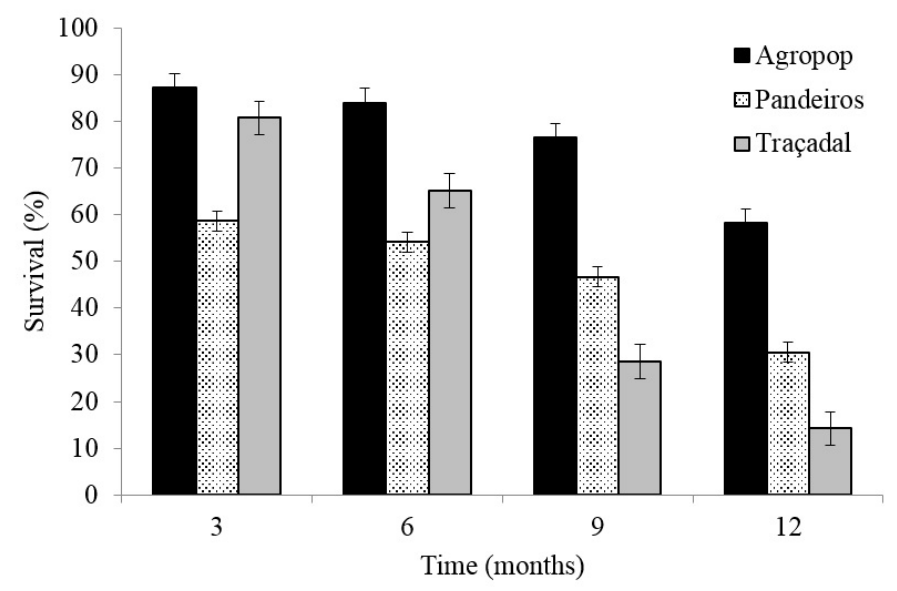

Figure 3. Average survival percentage of saplings planted for the rehabilitation of riparian vegetation of Pandeiros river (Januária, MG), for restoration areas and evaluation time. 
Table 2. Average survival percentage in time and standard deviation (in parentheses) of the species implanted in the recovery of riparian vegetation of Pandeiros river (Januária, MG). Popular names, species' authors name and their respective botanical families are presented in Table 1.

\begin{tabular}{|c|c|c|c|c|}
\hline \multirow{2}{*}{ Species } & \multicolumn{4}{|c|}{ Survival (\%) } \\
\hline & 3 months & 6 months & 9 months & 12 months \\
\hline A. colubrina & $87.12( \pm 6.76)$ & $82.03( \pm 6.78)$ & $70.13( \pm 6.48)$ & $70.13( \pm 6.98)$ \\
\hline A. crassiflora & $76.19( \pm 9.21)$ & $64.45( \pm 9.28)$ & $39.25( \pm 10.09)$ & $15.83( \pm 9.56)$ \\
\hline A. fraxinifolium & $80.33( \pm 6.73)$ & $75.86( \pm 6.78)$ & $61.86( \pm 7.36)$ & $45.92( \pm 17.04)$ \\
\hline A. humile & $57.43( \pm 18.43)$ & $47.32( \pm 18.57)$ & $42.85( \pm 20.18)$ & $8.03( \pm 19.12)$ \\
\hline A. occidentale & $60.10( \pm 18.43)$ & $52.65( \pm 18.57)$ & $26.59( \pm 20.19)$ & $20.21( \pm 9.12)$ \\
\hline A. subincanum & $61.25( \pm 10.64)$ & $61.25( \pm 10.72)$ & $50.17( \pm 11.65)$ & $24.73( \pm 11.03)$ \\
\hline C. americana & $78.56( \pm 18.43)$ & $78.57( \pm 18.57)$ & $64.28( \pm 20.18)$ & $35.71( \pm 19.12)$ \\
\hline C. coriacea & $57.07( \pm 6.96)$ & $46.66( \pm 7.02)$ & $35.29( \pm 7.62)$ & $18.48( \pm 7.22)$ \\
\hline C. dumosum & $84.02( \pm 9.85)$ & $78.82( \pm 9.92)$ & $70.93( \pm 10.78)$ & $42.92( \pm 17.04)$ \\
\hline C. ferrea & $93.74( \pm 13.03)$ & $93.74( \pm 13.13)$ & $74.99( \pm 14.27)$ & $63.88( \pm 13.64)$ \\
\hline C. iguanaea & $90.45( \pm 18.43)$ & $70.45( \pm 18.57)$ & $65.90( \pm 20.18)$ & $29.09( \pm 19.02)$ \\
\hline C. leptophloeus & $82.94( \pm 10.64)$ & $74.74( \pm 10.72)$ & $47.59( \pm 11.65)$ & $40.83( \pm 11.03)$ \\
\hline C. pachystachya & $47.95( \pm 7.23)$ & $34.85( \pm 7.28)$ & $26.57( \pm 7.91)$ & $16.34( \pm 7.49)$ \\
\hline D. bipinnatum & $61.40( \pm 7.52)$ & $58.26( \pm 7.58)$ & $47.38( \pm 8.26)$ & $28.42( \pm 7.80)$ \\
\hline E. contortisiliquum & $77.22( \pm 7.86)$ & $69.32( \pm 7.91)$ & $61.79( \pm 6.06)$ & $47.71( \pm 8.22)$ \\
\hline E. dysenterica & $45.33( \pm 9.21)$ & $41.64( \pm 9.28)$ & $30.80( \pm 10.09)$ & $17.70( \pm 9.56)$ \\
\hline G. americana & $92.56( \pm 9.85)$ & $80.90( \pm 9.92)$ & $44.59( \pm 6.78)$ & $34.14( \pm 10.22)$ \\
\hline G. ulmifolia & $77.41( \pm 7.52)$ & $70.23( \pm 7.58)$ & $47.80( \pm 6.23)$ & $31.88( \pm 7.80)$ \\
\hline H. chrysotrichus & $93.66( \pm 9.85)$ & $84.84( \pm 9.55)$ & $77.57( \pm 10.78)$ & $51.55( \pm 10.31)$ \\
\hline Hymenaea sp. & $61.32( \pm 6.75)$ & $55.66( \pm 6.78)$ & $40.34( \pm 7.36)$ & $28.04( \pm 6.98)$ \\
\hline I. vera & $28.94( \pm 26.07)$ & $13.15( \pm 26.26)$ & 0 & 0 \\
\hline J. brasiliana & $98.19( \pm 13.03)$ & $96.76( \pm 13.13)$ & $96.05( \pm 14.27)$ & $85.00( \pm 13.54)$ \\
\hline M. pubescens & $50.88( \pm 6.73)$ & $43.52( \pm 6.78)$ & $34.49( \pm 7.36)$ & $24.39( \pm 6.98)$ \\
\hline M. urundeuva & $77.00( \pm 6.51)$ & $74.24( \pm 6.56)$ & $63.89( \pm 6.13)$ & $42.78( \pm 6.75)$ \\
\hline S. brasiliensis & $71.57( \pm 6.96)$ & $69.82( \pm 7.02)$ & $57.29( \pm 7.62)$ & $38.10( \pm 7.22)$ \\
\hline S. polyphylla & $58.43( \pm 9.85)$ & $48.81( \pm 9.92)$ & $43.90( \pm 10.78)$ & $23.89( \pm 10.22)$ \\
\hline S. spectabilis & $87.04( \pm 9.21)$ & $84.63( \pm 9.28)$ & $81.47( \pm 10.09)$ & $68.81( \pm 9.56)$ \\
\hline S. striata & $57.27( \pm 10.64)$ & $57.27( \pm 10.72)$ & $55.42( \pm 11.65)$ & $28.40( \pm 11.03)$ \\
\hline T. esculenta & $93.25( \pm 10.64)$ & $78.13( \pm 10.72)$ & $56.64( \pm 11.65)$ & $35.88( \pm 11.03)$ \\
\hline T. gardneriana & $85.54( \pm 8.69)$ & $85.24( \pm 8.75)$ & $81.55( \pm 9.51)$ & $69.33( \pm 9.09)$ \\
\hline Tabebuia sp. & $76.16( \pm 6.51)$ & $63.33( \pm 6.56)$ & $44.73( \pm 7.13)$ & $26.64( \pm 6.75)$ \\
\hline V. macrocarpa & $31.25( \pm 13.03)$ & $31.25( \pm 13.13)$ & $31.25( \pm 14.27)$ & $25.00( \pm 13.51)$ \\
\hline Z. joazeiro & $50.10( \pm 10.64)$ & $40.79( \pm 10.72)$ & $22.11( \pm 11.65)$ & $1.50( \pm 11.03)$ \\
\hline Total & $70.32( \pm 1.76)$ & $64.00( \pm 1.80)$ & $51.01( \pm 1.90)$ & $34.41( \pm 1.82)$ \\
\hline
\end{tabular}

\section{DISCUSSION}

The first year of planting is considered a period of sapling adaptation to the adverse conditions present at the site being revegetated, and is therefore when seedlings present higher mortality (Mcdonald et al., 2003; Raman et al., 2009). The decrease in survival rates over the first year of evaluation may also be related to the climatic conditions of the region, since the rains are concentrated in the months of November to January
(Azevedo et al., 2014). The saplings were introduced during the rainy season (December and January), after which they went through a long period of drought during autumn and winter (April to October), until the arrival of the next rainy season in the summer. Therefore, water deficits may have led to the death of the plants, since low soil moisture is a limiting factor for the development of saplings (Paiva \& Poggiani, 2000). McDonald et al. (2003), in a study with native species implanted in a revegetation area in Jamaica, 
found a survival rate (39 to $48 \%$, after 12 months) similar to the present study. Rezende (2004), in a restoration of gallery forests in 88 rural properties in the Distrito Federal (Brazil), obtained lower survival data than that of the present study, with the survival of only $16.3 \%$ of the saplings planted.

Although fenced, the three study areas were affected by the presence of cattle within the plots, a factor that may have contributed to the decreased survival rates of the saplings, especially in the Pandeiros and Traçadal areas, where this influence was more intense. This fact was due to the possibility of animals entering via the river, during periods of drought, and when the fence was damaged. In addition, several studies (Figueiras, 1990; Martins et al., 2004; Rossi et al., 2010) cite the aggressiveness and high competitiveness of African grasses introduced into Brazil, such as Brachiaria species with native plants. In a study by Figueiras (1990), which classified African grasses according to aggressiveness in terms of competition with native flora, eight species of the Brachiaria genus were classified as "very aggressive" and "moderately aggressive", seriously affecting natural regeneration. Thus, exotic grasses used in pasture formation may be an aggravating factor in the mortality of seedlings planted in recovery projects in areas impacted by cattle breeding.

In addition to competition and climatic conditions, survival may be related to factors such as soil type and drainage (McDonald et al., 2003). According to Braga (2011), in an experiment to evaluate the performance of saplings and the development of natural regeneration in different recovery models in the AGROPOP area, half of the plots of this area are located in places originally influenced by dry forest formation with very nutrient rich soils. The soil analysis for this area, according to Braga (2011), found high levels of phosphorus and a higher proportion of clay in these plots. Several authors discuss the positive influence of soil on plant establishment (Alpert et al., 1999; Gurevitch et al., 2009). These same authors cite the importance of phosphorus as a limiting nutrient for the development of plants, as a constituent in several molecules and in cell membranes, acting directly on plant metabolism, and essential for the initial development of seedlings. Moreover, clay is a component that ensures greater soil moisture, providing water to the plants for longer periods during the dry season (Gurevitch et al., 2009) thus ensuring their survival.
The species with the highest survival rates (J. brasiliana, A. colubrina, T. gardneriana, S. spectabilis and C. ferrea), are characterized as pioneer species, heliophytes, fast growing, and are used in heterogeneous reforestation and recovery of degraded areas (Lorenzi, 1992, 1998; Carvalho, 2003, 2010). Lorenzi (2002) points out that because of the rusticity and adaptation to dry lands, the various angico species are recommended for rehabilitation, as they grow well in poor and degraded soils, as well as having very rapid growth, being ready for field planting in less than four months. Barbosa (1980) pointed out that saplings of the genus Anadenanthera supported relative humidity ranging from $1 \%$ to approximately zero, losing 85 to $90 \%$ of the initial water content, and recovering turgidity when rehydrated, showing the adaptation of species to the irregular precipitation regime. Among the 10 species with the best development (high survival and rapid growth) found in the recovery of gallery forests on rural properties in the Distrito Federal, Rezende (2004) indicates J. brasiliana and A. colubrina (38.5\% and $21.9 \%$, respectively). These species maintained a high adaptive plasticity when confronted by the adverse conditions found in the field (Rezende, 2004), which can also be observed in this study. It is of paramount importance to consider the adaptability of the species to the place where they will be introduced, since, in degraded areas, adverse conditions may decrease species survival (Rezende, 2004; Martins, 2007).

Although Inga vera is a heliophyte, pioneer or initial succession species (Carvalho, 2008), in the present study, the saplings of this species that were planted showed $100 \%$ mortality after one year. Probably, the mortality of the species is related to water scarcity during the dry period in the study area, since according to Carvalho (2008), Inga vera occurs naturally in moist, frequently humid soils and even in swampy areas. Neri et al. (2011) emphasized that the identification of native species, with good development in degraded areas, is an important step in the implementation of recovery projects. These authors also argued that the correct choice of species for revegetation in Cerrado areas should take into account their need to adapt to low soil fertility, possible water deficits or flooding and an ability to compete with invasive weeds; factors that may determine the survival and growth of saplings.

Studies involving edaphic and environmental variables are necessary for a better understanding of 
the survival of the seedlings within the tested recovery models. Such studies are scarce, since there are few studies investigating the recovery of degraded areas that use native plants and that propose recovery models to be tested, which makes it difficult to compare the methods analyzed here.

\section{CONCLUSION}

The average survival of the saplings planted was low, probably due to the adverse conditions found in the degraded sites, such as long periods of water stress characteristic of the region and possible external interference, such as competition from Brachiaria sp. or trampling and grazing by domesticated animals. Some species are more resistant, such as Jacaranda brasiliana, Anadenanthera colubrina, Triplaris gardneriana, Senna spectabilis and Caesalpinia ferrea, and may be suitable for revegetation in degraded riparian forests in the Pandeiros river region. Additionally, the models tested should be reevaluated to give sufficient time for planted individuals to compete with their peers.

\section{ACKNOWLEDGEMENTS}

The authors wish to thank CNPq (Conselho Nacional de Desenvolvimento Científico e Tecnológico; 577460/2008-0; 306375/2016-8), FAPEMIG (Fundação de Amparo à Pesquisa do Estado de Minas Gerais; APQ-00627-16) and CAPES (Coordenação de Aperfeiçoamento de Pessoal de Nível Superior) for grant funding for this research. We would also like to thank IEF (Instituto Estadual de Florestas), UNIMONTES (Universidade Estadual de Montes Claros) and the Promotoria de Justiça de Defesa da Bacia do Rio São Francisco, for logistical and legal support; Dr. Rubens Manoel dos Santos (Universidade Federal de Lavras), for help with botanical identification; all the students of Laboratório de Ecologia Vegetal (UNIMONTES) and IEF staff, for field assistance; and the farm owners José Fernando Coura (AGROPOP farm), Hildo Fortunato Pinto (Pandeiros farm) and Ana Lúcia Gallo da França (Traçadal farm), for permission to conduct this research.

\section{SUBMISSION STATUS}

Received: 10 nov., 2015

Accepted: 23 jan., 2017

\section{CORRESPONDENCE TO}

\section{Yule Roberta Ferreira Nunes}

Departamento de Biologia Geral, Universidade

Estadual de Montes Claros - UNIMONTES

Av. Dr. Ruy Braga, s/n, Vila Mauricéia

CEP 39401-089, Montes Claros, MG, Brazil

e-mail: yule.nunes@unimontes.br

\section{FINANCIAL SUPPORT}

CNP, FAPEMIG and CAPES.

\section{REFERENCES}

Alpert P, Griggs FT, Peterson DR. Riparian forest restoration along large rivers: initial results from the Sacramento River Project. Restoration Ecology 1999; 7(4): 360-368. http:// dx.doi.org/10.1046/j.1526-100X.1999.72030.x.

Andel JV, Grootjans AP, Aronson J. Unifying concepts. In: Andel JV, Aronson J, editors. Restoration ecology: the new frontier. Chichester: Wiley-Blackwell; 2012. p. 9-22.

Azevedo IFP, Nunes YRF, Ávila MA, Silva DL, Fernandes GW, Veloso RB. Phenology of riparian tree species in a transitional region in southeastern Brazil. Brazilian Journal of Botany 2014; 37(1): 47-59. http://dx.doi.org/10.1007/ s40415-014-0046-5.

Barbosa DCA. Estudos ecofisiológicos em Anadenanthera macrocarpa (Benth.) Brenan - aspectos de germinação e crescimento [tese]. São Paulo: Universidade de São Paulo; 1980.

Beltrame TP, Rodrigues E. Comparação de diferentes densidades de feijão guandu (Cajanus cajan (L.). Millsp.) na restauração florestal de uma área de reserva legal no Pontal do Paranapanema, SP. Scientia Florestalis 2008; 36: 317-327.

Braga LL. Performance de mudas e desenvolvimento da regeneração natural em diferentes modelos de restauração em uma floresta ciliar no sudeste do Brasil [dissertação]. Montes Claros: Universidade Estadual de Montes Claros; 2011.

Brasil. Lei Federal no 12.651, de 25 de maio de 2012. Revoga as Leis $n^{\circ} 4.771$, de 15 de setembro de 1965, e 7.754, de 14 de abril de 1989, e a Medida Provisória no 2.166-67, de 24 de agosto de 2001; e Institui o Novo Código Florestal. Diário Oficial da República Federativa do Brasil, Brasília, DF (2012).

Brasil. Lei Federal no 4.771, de 15 de setembro de 1965. Institui o Novo Código Florestal. Diário Oficial da República Federativa do Brasil, Brasília, DF (1965).

Carvalho PER. Espécies arbóreas brasileiras. Vol. 1. Brasília: Embrapa Florestas; 2003. 
Carvalho PER. Espécies arbóreas brasileiras. Vol. 3. Brasília: Embrapa Florestas; 2008.

Carvalho PER. Espécies arbóreas brasileiras. Vol. 4. Brasília: Embrapa Florestas; 2010.

Figueiras TS. Africanas no Brasil: gramíneas introduzidas da África. Cadernos de Geociências 1990; 5: 57-63.

Gonçalves RMG, Giannotti E, Giannotti JG, Silva AA. Aplicação de modelo de revegetação em áreas degradadas, visando à restauração ecológica da microbacia do córrego da Fazenda Itaqui, no município de Santa Gertrudes, SP. Revista Instituto Florestal 2005; 17(1): 73-95.

Gurevitch J, Scheiner SM, Fox GA. Ecologia vegetal. São Paulo: Editora Artmed; 2009.

Hughes FMR, Moss T, Richards KS. Uncertainty in riparian and floodplain restoration. In: Darby S, Sear D. River restoration: managing the uncertainty in restoring physical habitat. Chichester: Wiley; 2008.

Instituto Nacional de Metereologia - INMET. Banco de dados meteorológicos para ensino e pesquisa [online]. Brasília: INMET; 2016. [cited 2016 Sep 17]. Available from: http://www.inmet.gov.br

Jacomine PKT. Conceituação sumaria de classes de solos e critérios para subdividi-las. Rio de Janeiro: EMBRAPASNLCS; 1979.

Klink CA, Machado RB. A conservação do Cerrado brasileiro. Megadiversidade 2005; 1: 148-155.

Lorenzi H. Árvores brasileiras: manual de identificação e cultivo de plantas arbóreas nativas do Brasil. Vol. 1. Nova Odessa: Plantarum; 1992.

Lorenzi H. Árvores brasileiras: manual de identificação e cultivo de plantas arbóreas nativas do Brasil. Vol. 2. Nova Odessa: Plantarum; 1998.

Lorenzi H. Árvores brasileiras: manual de identificação e cultivo de plantas arbóreas nativas do Brasil. Vol. 3. Nova Odessa: Instituto Plantarum; 2002.

Martins CR, Leite LL, Haridasan M. Capim-gordura (Melinis minutiflora P. Beauv.), uma gramínea exótica que compromete a recuperação de áreas degradadas em unidades de conservação. Revista Árvore 2004; 28(5): 739747. http://dx.doi.org/10.1590/S0100-67622004000500014.

Martins SV. Recuperação de matas ciliares. Viçosa: Aprenda Fácil; 2007.

McClain DC, Holl DK, Wood DM. Successional Models as Guides for Restoration of Riparian Forest Understory. Restoration Ecology 2011; 19(2): 280-289. http://dx.doi. org/10.1111/j.1526-100X.2009.00616.X.

McDonald MA, Hofny-Collins A, Healey JR, Goodland TCR. Evaluation of trees indigenous to the montane forests of the Blue Mountains, Jamaica for reforestation and agroforestry. Forest Ecology and Management 2003; 175(1-3): 379-401. http://dx.doi.org/10.1016/S03781127(02)00132-9.
Menino GCO, Nunes YRF, Santos RM, Fernandes GW, Fernandes LA. Environmental heterogeneity and natural regeneration in riparian vegetation of the Brazilian semiarid region. Edinburgh Journal of Botany 2012; 69(1): 29-51. http://dx.doi.org/10.1017/S0960428611000400.

Neri AV, Soares MP, Meira-Neto JAA, Dias LE. Espécies de Cerrado com potencial para recuperação de áreas degradadas por mineração de ouro, Paracatu-MG. Revista Árvore 2011; 35(4): 907-918. http://dx.doi.org/10.1590/ S0100-67622011000500016.

Nunes YRF, Azevedo IFP, Neves WV, Veloso MDM, Souza RA, Fernandes GW. Pandeiros: o Pantanal Mineiro. $M G$. Biota 2009; 2(2): 4-17.

Paiva AV, Poggiani F. Crescimento de mudas de espécies arbóreas nativas plantadas no sub-bosque de um fragmento florestal. Scientia Forestalis 2000; 57: 141-151.

Pereira JS, Rodrigues SC. Crescimento de espécies arbóreas utilizadas na recuperação de área degradada. Caminhos de Geografia 2012; 13(41): 102-110.

$\mathrm{R}$ Development Core Team. $R$ : A language and environment for statistical computing [online]. Vienna: R Foundation for Statistical Computing; 2013. [cited 2015 May 25]. Available from: http://www.R-project.org

Raman TRS, Mudappa D, Kapoor V. Restoring Rainforest Fragments: survival of mixed-native species seedlings under contrasting site conditions in the Western Ghats, Índia. Restoration Ecology 2009; 17(1): 137-147. http:// dx.doi.org/10.1111/j.1526-100X.2008.00367.x.

Rezende RP. Recuperação de matas de galeria em propriedades rurais do Distrito Federal e entorno [dissertação]. Brasília: Universidade de Brasília; 2004.

Ribeiro JF, Schiavini I. Recuperação de matas de galeria: integração entre a oferta ambiental e a biologia das espécies. In: Ribeiro JF. Cerrado: matas de galeria. Planaltina: EMBRAPA-CPAC; 1998.

Rodrigues PMS, Azevedo IFP, Veloso MDM, Santos RM, Menino GC, Nunes YRF et al. Riqueza Florística da Vegetação ciliar do rio Pandeiros, norte de Minas Gerais. MG. Biota 2009; 2(2): 18-35.

Roni P, Beechie T. Stream and watershed restoration. Oxford: Wiley-Blackwell; 2013.

Rossi JP, Celini L, Mora P, Mathieu J, Lapied E, Nahmani JF et al. Decreasing fallow duration in tropical slash and burn agriculture alters soil macroinvertebrate diversity: a case study in southern French Guiana. Agriculture, Ecosystems \& Environment 2010; 135(1-2): 148-154. http:// dx.doi.org/10.1016/j.agee.2009.08.012.

Scariot A, Souza-Silva JC, Felfili JM. (Org.). Cerrado: ecologia, biodiversidade e conservação. Brasília: Ministério do Meio Ambiente; 2005.

Tilman D. Plant strategies and the dynamics and structure of plant communities (Monograph). Princeton: Princeton University Press; 1988. 
Universidade Federal de Viçosa - UFV. Centro Tecnológico de Minas Gerais - CETEC. Universidade Federal de Lavras - UFLA. Fundação Estadual do Meio Ambiente -FEAM. Mapa de solos do estado de Minas Gerais. Belo Horizonte: Fundação Estadual do Meio Ambiente; 2010a.

Universidade Federal de Viçosa - UFV. Centro Tecnológico de Minas Gerais - CETEC. Universidade Federal de Lavras - UFLA. Fundação Estadual do Meio Ambiente -
FEAM. Mapa de solos do Estado de Minas Gerais: legenda expandida. Belo Horizonte: Fundação Estadual do Meio Ambiente; 2010b.

Veloso MDM, Nunes YRF, Azevedo IFP, Rodrigues PMS, Fernandes LA, Santos RM et al. Floristic and structural variations of the arboreal community in relation to soil properties in the Pandeiros river riparian forest, Minas Gerais, Brazil. Interciencia 2014; 39(9): 628-636. 